\title{
Process of forming a regional recreation system in the conditions of a border region
}

\author{
Anastasia Vasilieva $^{* 1}$, Raisa Belaya $^{1}$ \\ ${ }^{1}$ Karelian Research Centre of the Russian Academy of Sciences (Institute of Economics), Al. Nevsky \\ Prospect, 50, Petrozavodsk, 185030, Russia
}

\begin{abstract}
Significant heterogeneity of the level of development of the Russian border, including in the field of recreation, imposes requirements for differentiation in the regional policy. Definition of the types of territories helps to solve applied management tasks more effectively. In this context, the factors by which these types were formed are important. To solve this problem, the authors conducted a factor analysis through the principal component method using oblique factor rotation. Three blocks of variables were analyzed that characterize the subjects of the Russian Federation that have land borders on the mainland (including river and lake borders) and sea borders with neighboring countries located on the map clockwise from Norway to the United States (border regions of Russia) for the period from 2010 to 2018. As a result, five factors were identified: the factor of the demand for the services of the recreational system, the factor of the development of the infrastructure of the recreational system in climatic conditions, the environmental safety factor, the factor of investment in the development of the recreational system infrastructure, the factor of the location at the border. The results of the study can be used as a practical tool for developing recommendations in the field of regional policy aimed at development of a recreational system, taking into account the factors determined for each identified group. The results of the study were obtained in the framework of the state task of the IE KarRC RAS on the topic "Institutions and social inequality in the face of global challenges and regional restrictions".
\end{abstract}

\section{Introduction}

In the spatial development strategy of the Russian Federation for the period until 2025, the territories specializing in the development of tourism and recreation are identified as the regional centers of economic growth. Organization of territorial social systems can significantly affect the quality of life of the people in the region and the nature of the processes in the system in the setting of such unfavorable trends as a high level of interregional socio-economic inequality, a significant lag in the key socio-economic indicators of the average Russian level of some Russian regions of geostrategic importance, significant intra-regional differences in the level of socio-economic development, including

*Corresponding author: vasnask@gmail.com 
lower living standards of a significant part of the population of rural areas in comparison with the standards of living of urban residents, as well as low levels of entrepreneurial activity in most small and medium-sized cities as well as in rural areas.

The conditions in Russia are characterized by imbalances in socio-economic development that manifest themselves to varying degrees, affecting the aspects of the development and formation of economic systems. One of such factors is the bordering position of the region, which has an impact on the regional systems. A recreational system as a compound socio-economic complex is built into the economy of the regions, and recreational activities that are aimed at the people's recuperation and rest are associated with the process of forming the quality of human capital in the regions and the country as a whole.

Current trends in economic development confirm changes in the structure of the world and national economies in the direction of increasing the contribution of the services sector, which includes recreational activities. The main positive effects from the development of recreational activity include improving the quality of the human capital, initiating job creation due to the relatively high workload in this field and attracting investments into the infrastructure facilities. However, the high recreational potential of the territory does not guarantee the successful development of tourism and the manifestation of the corresponding positive social and economic effects. Optimal spatial organization is a prerequisite for an effective, stable and integrated sustainability of recreational resources. Thus, spatial organization of territorial recreational systems is associated not only with attempts to achieve economic goals, but also with environmental and social aspects and compliance with science-based exposure standards. The spatial patterns of the formation of recreational systems in the context of a socio-economic regional space are a relevant applied task.

Significant heterogeneity of the level of development of the Russian border, including in the field of recreation, imposes requirements for differentiation in the regional policy. Definition of the types of territories helps to solve applied management tasks more effectively. In this context, the factors by which these types were formed are important. The economic task of typologization comes down to the definition of homogeneous groups when conducting interregional comparisons according to certain parameters (variables). Developing a system of these variables is a difficult scientific task. In its formation, it is necessary to strive to ensure that each indicator is necessary and at the same time the system of the parameters itself is sufficient to describe the patterns of development of the objects of study.

\section{Materials and Methods}

Currently, there is significant scientific groundwork in the field of cross-border tourism and recreation research in Russia and abroad. These are the works of such authors as R. Butler, M. Baud-Bovy, H. Wachowiak, J. Wall, Z. Gal, T. Greer, M. Koskinen, R. Lagiewski, J. O. J. Lundgren, J. Lane, J. M. Miosek, M. Oppermann, S. Plog, E. K. Prokkola, D. Revelas, W. Smith, T. Studzieniecky, D. Timothy, K. Fodeb, K. Jakosuo. It is important to clarify the concepts of border and cross-border tourism. In this study, border tourism is considered as traveling of consumers of recreational services from different countries along the border of two countries with its intersection. Cross-border tourism, on the other hand, is a subtype of border tourism with the crossing of the border of one or more states in order to visit several countries within one trip.

In Russia, the topics of cross-border interactions and the features of border region development are extensively studied in the works of P. Baklanov, P. Druzhinin, M. Zamyatina, S. Kuznetsov, T. Kuchinskaya, V. Kolosov, A. Leont'ev, N. Mezhevich, T. 
Morozova, V. Razumovsky, V. Shlyamin.

In his work, P. Baklanov examines the occurrence of cross-borderness in the Primorsky Territory and the border provinces of China. Based on the theoretical geographical generalization of cross-border structures to the regular geometric shapes, aimed at identifying their universality and uniqueness, conclusions were drawn about the qualitative transformation of the studied territorial structures and their expression in the form of theoretical (ideal) models. Such models make it possible to understand the essence of the unified geographical process of the territorial organization of the nature, population, and economy of individual regions, including cross-border ones [1].

One study examines the motives of cross-border Russian activities. The analysis shows that traditional investment motives provide a limited explanation of what attracts or deters Russian acquirers abroad. The authors include the institutional distance parameter in the model and prove that it plays a decisive role in building cross-border business interactions $[2]$.

A study by an international team of authors examines the cross-border relationships of three regionally significant and interconnected sectors (forestry, mining and tourism industry, together with the corresponding research and administrative organizations) with various strategies for using natural resources in the border region of Finland and Russia. The authors conclude that the network under study is not sufficiently developed, there is a low level of participation of companies with low integration between sectors. This may be a disadvantage in the sustainable development of border regions. However, the formed crossborder network does not only depend on the connections, but also consists of several moderately connected cross-border entities that increase its resistance to cross-border network failures [3].

A study by colleagues from the Institute of Geography of the Russian Academy of Sciences presents a research of the dynamics and factors of cross-border interactions, which are studied together with the dynamics of the barrier function that impedes or facilitates contacts between adjacent territories. A comparative analysis of interactions with neighboring territories in different border regions of Russia revealed a different nature of the dependences of the flows on the barrier functions of borders. In result, a typology of Russian border territories was compiled, based on indicators related to the contact and barrier function of the border and its impact on the daily life of the population [4].

The aspects of the development of recreational activities in the border regions are studied to a lesser extent. Noteworthy are the works of A. Aleksandrova, T. Gerasimenko, Yu. Dmitrievsky, I. Dragileva, A. Dunets, N. Zaitseva, A. Zyryanov, N. Kazakova, G. Karpova, V. Korneevets, E. Kropinova, Yu. Mazhar, D. Mirzekhanova, A. Mitrofanova, D. Nikolaenko, B. Rodoman, D. Sevast'yanova, S. Stepanova, A. Weidenfeld.

Here are some of these studies. To identify the problems of and prospects for the development of cross-border cooperation between the Russian Federation and European countries in the field of tourism, E. Kropinova and N. Zaitseva study in their work the scientific-theoretical aspects of cross-border cooperation and the role played by the tourism and recreation potential of the territories and its effective use. The analysis of statistical data and the results of their own research allowed the authors to identify the main problems that impede the development of cross-border cooperation in the field of recreation in the border territories of Russia and European countries. As economic problems, they highlight the negative impact of bilateral sanctions and the decrease in the financial stability of enterprises. In the social sphere, such problems as the worsening of the situation with migrants, the introduction of various institutional restrictions, and the general decrease in the attractiveness of Russian and European places of recreation in terms of the price-quality ratio have been identified [5].

A number of works in the field of study of cross-border tourism by S. Stepanova form a 
comprehensive idea of the developmental features and the main factors of influence. The author identifies the main types of tourism in the studied border territory, analyzes the recreational flows and strategic aspects of the development of recreational activities [6]. Based on the comparison of the data, the advantages and limitations of the development of tourism and recreation are revealed. The role of international checkpoints in the development of tourism in the border region is substantiated [7]. The international practice of using the phenomenon of state borders as a resource for the development of recreational activities is summarized. Based on these results, the author develops recommendations to increase the positive contribution of recreational activities to the economy of border regions [8].

A team of authors from the Smolensk University for Humanities focused their research on studying the theoretical issues of analysis and development of tourism in border regions. The analytical nature of the work made it possible to clarify the concept of "border region" and apply a geosystemic approach to the study of cross-border tourism. The authors conclude that the process of integration of the Russian tourist market in the world so far is spontaneous; there is no unified organizational-economic mechanism. In this case, the most effective step in that direction could be the development of tourism in the border regions based on the formation of cross-border and border tourist and recreational clusters [9].

In one of the works devoted to the study of cross-border tourism, the influence of recreational mobility on the promotion of innovative processes in border regions is studied. The author identified the aspects that shape and strengthen innovation in cross-border tourism and the transfer of knowledge in the context of the European policy of integration and unity. It is concluded that many smaller and more peripheral European border regions will increase their competitive advantages by promoting innovations in public services and tourism [10].

In the study of the processes of development of recreational activities in the GermanCzech border territories, specific obstacles in the field of organization and management that are associated with political contradictions in cross-border cooperation in the field of tourism were identified. Local tourism projects are generally successful both at the transnational and national levels, but there is a need for institutional alignment [11].

Works devoted to regional studies based on the use of multidimensional statistical analysis tools deserve special attention. In their work, S. Abramyan, E. Ryumina and A. Fedotova carried out an inter-regional analysis to assess the level of human potential in Russian regions and to determine the relationship with the global development goals for the period until 2030. The authors developed a system of 16 indicators for 85 regions of Russia describing eight goals and conducted a correlation analysis based on the data. The results obtained made it possible to formulate development strategies for the sustainable development program for individual regions [12].

In the work of M. Khavinson and A. Kolobov the dynamics of the employed population are modeled by economic sectors, both at the national and regional levels. The authors use agent-based modeling to study systematic processes in the labor market, which in turn lead to different dynamics in the number of people employed in economic sectors. According to the results of the study, it was determined that personal strategies for choosing a labor activity by economic agents become significant. Thus, strata with a dynamically changing number of employees are forming on regional labor markets [13].

Here is one of the works aimed at typologization of regions. A high level of differentiation of regional development makes it necessary to distinguish the types of regions, for example, according to the level of financial independence. According to the authors, this will help to identify the special aspects of strategizing. To achieve this goal, cluster analysis, the method of principal components and analysis of panel data were used. A system of 18 indicators of financial independence of the regions was developed. Based 
on these data, a cluster analysis was carried out, according to the results of which, three groups of regions were identified: leading regions, middle-level regions, outsider regions. The authors believe that the typology obtained can be used by authorities and regional governments to form regional and sectoral development strategies [14].

\section{Results}

In this article, a regional recreational system is understood as a compound socio-health complex aimed at restoring the strength and health of a person. The basis of a recreational system are the subjects of tourism, and the target function is the most complete satisfaction of recreational needs. A recreational system typically includes tourists, natural and cultural resources, a recreational infrastructure, professional staff and management structures. It must be clarified that recreational activities in the article are understood as one of the main types of human activity. This type of activity is aimed at relaxation and restoration of physical strength, intellectual improvement. An important characteristic of the process is its value, and not just its focus on obtaining a result. Thus, from the point of view of definition of the thesaurus of this study, recreation as a category implying restoration and maintenance of people's health and ability to work through tourism and recreation in nature and in an urban environment combines the concepts of tourism and relaxation.

To develop a practice-oriented scientific toolkit in the field of tourism and recreation development management at the regional level, it is proposed to apply an approach based on the identification of factors that take into account integrated ideas about the border region. To solve this research problem, the authors conducted a factor analysis using the principal component method using oblique factor rotation. Three blocks of variables (Table 1) were analyzed that characterize the subjects of the Russian Federation that have land borders on the mainland (including river and lake borders) and sea borders with neighboring countries located on the map clockwise from Norway to the United States (border regions of Russia).

Table 1 Variables for clustering border regions

\begin{tabular}{|c|c|}
\hline Blocks & Variables \\
\hline $\begin{array}{l}\text { Block } 1 \text { - the level } \\
\text { of social, } \\
\text { economic and } \\
\text { environmental } \\
\text { status of the } \\
\text { region }\end{array}$ & $\begin{array}{l}\text { - The integral rating of the region } \\
\text { - The climate discomfort level } \\
\text { - The environmental stress index }\end{array}$ \\
\hline $\begin{array}{l}\text { Block } 2 \\
\text { quantitative } \\
\text { characteristics of } \\
\text { the recreational } \\
\text { system of the } \\
\text { region }\end{array}$ & $\begin{array}{l}\text { - The density of international checkpoints (available cargo-passenger / passenger, } \\
\text { automobile, airline, railway, sea, mixed, river, lake, pedestrian checkpoints per } 100 \\
\mathrm{~km} \text { of the border) } \\
\text { - The number of accommodation facilities per } 1 \text { thousand } \mathrm{km}^{2} \text { (pcs.) } \\
\text { - The number of tourist companies per } 1 \text { thousand } \mathrm{km}^{2} \text { (pcs.) } \\
\text { - The density of specially protected natural areas }\end{array}$ \\
\hline $\begin{array}{l}\text { Block } 3 \\
\text { economic } \\
\text { characteristics of } \\
\text { the recreational } \\
\text { system of the } \\
\text { region }\end{array}$ & $\begin{array}{l}\text { - The share of the volume of paid services of hotels and similar accommodation } \\
\text { facilities in the GRP } \\
\text { - The number of foreign citizens accommodated in hotels and similar } \\
\text { accommodation facilities (per } 100,000 \text { people (residents of the region) } \\
\text { - The number of Russian citizens accommodated in hotels and similar } \\
\text { accommodation facilities (per } 100,000 \text { people (residents of the region) } \\
\text { - The share of investment in the development of collective accommodation } \\
\text { facilities in the total investment in the region } \\
\text { - The share of paid tourist services in the GRP } \\
\text { - The average annual load in collective accommodation facilities in } \%\end{array}$ \\
\hline
\end{tabular}

Table 2 Factors of the formation of the spatial organization of the recreational system of the region 


\begin{tabular}{|c|c|c|}
\hline Factors & Variables & Loadings \\
\hline $\begin{array}{l}\text { F1. A demand factor } \\
\text { for the services of the } \\
\text { recreational system }\end{array}$ & $\begin{array}{l}\text { - V3. The share of the volume of paid services of hotels and similar } \\
\text { accommodation facilities in the GRP } \\
\text { - V5. The number of foreign citizens accommodated in hotels and } \\
\text { similar accommodation facilities (per } 100,000 \text { people (residents of } \\
\text { the region) } \\
\text { - V6. The number of Russian citizens accommodated in hotels and } \\
\text { similar accommodation facilities (per } 100,000 \text { people (residents of } \\
\text { the region) } \\
\text { - V14. Number of recorded crimes (per } 100,000 \text { ) }\end{array}$ & $\begin{array}{l}.842 \\
.774 \\
.898 \\
.681\end{array}$ \\
\hline $\begin{array}{l}\text { F2. The factor of the } \\
\text { development of the } \\
\text { infrastructure of the } \\
\text { recreational system in } \\
\text { climatic conditions }\end{array}$ & $\begin{array}{l}\text { - V2. The number of accommodation facilities per } 1 \text { thousand } \mathrm{km} 2 \\
\text { (pcs.) } \\
\text { - V15. The number of tourism companies per } 1 \text { thousand } \mathrm{km} 2 \text { (pcs.) } \\
\text { - V9. The climate discomfort level }\end{array}$ & $\begin{array}{l}.911 \\
.834 \\
.564\end{array}$ \\
\hline $\begin{array}{l}\text { F3. } \\
\text { environmental safety } \\
\text { factor }\end{array}$ & $\begin{array}{l}\text { - V7. The average annual load in collective accommodation } \\
\text { facilities in } \% \\
\text { - V10. The environmental stress index } \\
\text { - V12. The integral rating of the region }\end{array}$ & $\begin{array}{l}.581 \\
-.753 \\
.672\end{array}$ \\
\hline $\begin{array}{l}\text { F4. The investment } \\
\text { factor in the } \\
\text { infrastructure of the } \\
\text { recreational system }\end{array}$ & $\begin{array}{l}\text { - V8. The share of investment in the development of collective } \\
\text { accommodation facilities in the total investment in the region } \\
\text { - V13. The density of specially protected natural areas }\end{array}$ & $\begin{array}{l}.862 \\
.594\end{array}$ \\
\hline $\begin{array}{l}\text { F5. The factor of the } \\
\text { location at the } \\
\text { border }\end{array}$ & $\begin{array}{l}\text { - V11. The density level of international checkpoints } \\
\text { - V4. The share of paid tourist services in the total production of } \\
\text { goods and services in the region }\end{array}$ & $\begin{array}{l}.883 \\
.505\end{array}$ \\
\hline
\end{tabular}

\section{Discussion}

As a result of the factor analysis, concentrated initial information expressing a large number of features through the developed system of indicators is formulated as a number of factors. The interpretation of the identified factors is reasonable and is relevant to the indicators characterizing the factors, which allows the authors of the article to consider the results successful.

The first factor is formulated as a demand factor for the services of the recreational system. It is associated with the number of foreign and Russian citizens registered in hotels and similar accommodation facilities and the volume of paid services. In addition, in the formation of this factor, the variable demonstrating the level of security in the region expressed through the number of recorded crimes played a significant role. In general, the services of a recreational system are considered as a complete list of both direct and related services connected with the provision of leisure processes, while organizations that provide such services form a large regional sector of the economy. At the stage of the formation of the variable system, during the analysis of the correlation between the variables, it was determined that the indicators characterizing the hotel industry are of the greatest importance. The indicators associated with the other services of the recreational system are strongly connected with and dependent on them.

The second factor - the factor of the development of the infrastructure of the recreational system in climatic conditions - was formed from the variables characterizing the concentration of such elements of the recreational system as hotel enterprises and tourist companies and the climatic parameter. The content of this factor demonstrates that the climate determines the spatial organization of regional recreational systems, and this parameter must be taken into account when organizing any types of recreational activities.

In the formation of the third factor - the environmental safety factor - the variable of environmental stress received a high negative loading. The environmental stress in the region is associated with the anthropogenic impact on the biosphere resources. The negative 
value of the factor loading here denotes the feedback of this attribute with the selected factor, which is associated with the meaning of the variable itself.

The loading analysis of the fourth factor - the investment factor in the infrastructure of the recreational system - shows the importance of the recreational potential, in this case, of the natural resources of specially protected natural areas, as a component of investment appeal. It can be concluded that regions with high resource potential in the field of development of recreational activities focused on natural resources generate the greatest investment interest.

The factor of the location at the border was formed as a combination where the greatest loadings were received by the variables characterizing the density level of available international checkpoints and the indicator related to the share of paid tourist services in the total volume of goods and services in the region. This validates the role of the border infrastructure in the processes of cross-border regionalization based on recreational activities with an appropriate contribution to the regional economy.

\section{Conclusions}

Russia has the largest number of neighboring countries in the world. The length of the border is more than $60,000 \mathrm{~km}$. Moreover, the Russian borderland can be characterized by prominent geopolitical, geographical and socio-economic differentiation. At the same time, the economic potential of the Russian border territories creates significant opportunities for the development of various forms of cooperation, including in the field of recreational activities. In recent years, the nature of cross-border interactions has changed. The rental speculative model is being replaced by a model, which is based on the ideas of developing small and medium-sized businesses in the production of goods and services.

Researchers of cross-border issues agree that the manifestation of the contact and barrier function of the border affects the development of the border subjects of the Russian Federation. At the same time, the recreational systems in the border regions are developing in the conditions of the formation of additional incentives due to the presence of the border.

In this article, factor analysis is considered as a method of monitoring processes that subsequently allows these processes to be designed in the system itself. Determination of the factors of the process of formation of a regional recreational system in the conditions of the border region will allow to clarify the development directions of recreational activities for groups of border regions with different potentials. The influence of the structure of budget expenditures on the pace of economic development is explained in the work of Kudrin and Knobel [15]. The results of the study can be used as a practical tool for developing recommendations in the field of regional policy aimed at development of a recreational system, taking into account the factors determined for each identified group and certain investment priorities. The results of the study were obtained in the framework of the state task of the IE KarRC RAS on the topic "Institutions and social inequality in the face of global challenges and regional restrictions".

\section{References}

1. P. Baklanov, V. Bocharnikov, E.G. Egidarev, IOP Conference Series: Earth and Environmental Science. 190(1), 012044, (2018), DOI: 10.1088/17551315/190/1/012044

2. D. Dikova, A. Panibratov, A. Veselova, International Business Review. 28(4), 625637, (2019), https://doi.org/10.1016/j.ibusrev.2018.12.007 
3. T. Makkonen, Timo J. Hokkanen, T. Morozova, M. Suharev, Eurasian Geography and Economics. 59:5-6, 685-707, (2018), https://doi.org/10.1080/15387216.2019.1593209

4. V. Kolosov, M Zotova, A. Sebentsov, Regional Research of Russia. 4, 387-397, (2016), DOI: 10.1134/S2079970516040092

5. N. Zaitseva, E. Kropinova, Balt. Reg. 3, 98-108, (2016), DOI: 10.5922/2074-98482016-3-8

6. S. Stepanova, Balt. Reg. 3, 147-163, (2016), DOI: 10.5922/2079-8555-2016-3-9

7. S. Stepanova, Balt. Reg. 2, 94-111, (2019), DOI:10.5922/2079-8555-2019-2-6

8. S. Stepanova, Balt. Reg. 2, 105-121, (2017), DOI: 10.5922/2074-9848-2017-2-6.

9. A. Katrovsky, Yu. Kovalev, L. Mazhar, S. Shcherbakova, Balt. Reg. 1, 113-126, (2017), DOI: 10.5922/2074-9848-2017-1-7.

10. A. Weidenfeld, Annals of Tourism Research. 42, 191-213 (2013), http://dx.doi.org/10.1016/j.annals.2013.01.003

11. A. Stoffelen, D. Ioannides, D. Vanneste, Annals of Tourism Research. 64, 126-138, (2017), https://doi.org/10.1016/j.annals.2017.03.003

12. S. Abramyan, E. Ryumina, A. Fedotov, Economics and Mathematical Methods. 55 (4), 57-67, (2019), DOI: 10.31857/S042473880006773-9juju

13. M. Khavinson , A. Kolobov, Computer Research and Modeling. 6, 919-937, (2018), DOI: $10.20537 / 2076-7633-2018-10-6-919-937$

14. M. Shakleina, A. Midov, Economic and Social Changes: Facts, Trends, Forecast. 3, 3954, (2019), DOI: 10.15838/esc.2019.3.63.3

15. A. Kudrin, A. Knobel, Russian Journal of Economics. 4(3), 197-214, (2018), DOI: 10.3GB897/j.ruje.4.30163 